the terminology is a little confusing. Two examples may be quoted. It has always been accepted that amorphous deposits of ice due to the freezing of water droplets are called rime, whereas crystalline sublimation forms are known as frost (or hoar); yet the author speaks of both crystalline and amorphous forms of both rime and frost. Again, the term 'powder snow' in this book seems to denote something different from the previously accepted meaning of the word as used by snow-craftsmen all over the world. These are insignificant criticisms compared with the general excellence of this work. The portrayals of snow crystals, upwards of 1,550 in number, are of really exquisite beauty and delicacy, and the book has been handsomely produced with assistance from both American and Japanese sources. In giving praise to the author one should not forget his many helpers, whose enthusiasm, one takes leave to suggest, Prof. Nakaya has himself stimulated.

G. SELIGMAN

\section{BIRDS OF THE SOUTH-WEST ASIAN DESERT}

\section{Birds of Arabia}

By Colonel R. Meinértzhagen. Pp. xiii $+624+28$ plates. (Edinburgh and London: Oliver and Boyd, Ltd., 1954.) 84s. net.

WO handsome volumes on the birds of Egypt from the same authoritative pen have long stood on the ornithologist's shelves. Now Colonel R. Meinertzhagen has flanked them with the present work on the area immediately to the east; he does not restrict himself to the political boundaries of Arabia, but deals with the whole desert area of south-west Asia. Based as it is on first-hand knowledge of a subject on which there has hitherto been only a scanty and scattered literature, the book will be a standard for many years to come.

The bulk of the book consists of the systematic account of the relevant species and geographical races, for each of which particulars are given. There are also family keys to identification, and sometimes a general discussion of a genus. Many of the forms are illustrated, in colour plates or text figures, and there are maps showing the entire distribution of various species and their component races.

Short notes (listed at p. 72) on a number of general topics are interpolated in the systematic account, and there are four introductory chapters dealing respectively with the physical characteristics of the area, with desert coloration, with distribution and migration, and with systematics and nomenclature. In these general discussions the author is usually provocative, often controversial, but always stimulating. Occasionally he digresses rather far from his main theme to voice some personal opinion.

On the vexed question of desert coloration, Colonel Meinertzhagen agrees that there is much that is not yet known or fully understood. He inclines strongly to the view that the characteristic colour of desert animals has been evolved as a protection against climate rather than against predators; and that, although pattern may often be of cryptic value, shades of colour are the result of environmental influences.

The author's view is that the bulk of the migration which must traverse the area, from western Asia to
East Africa, does so by way of the land-bridge at Sinai rather than on a broad front across the main desert. In the almost complete absence of local data, he bases this opinion on his experience of migration elsewhere; but the more direct approach to the question remains as an interesting task for future observers.

'There are nine photographic plates illustrating the country, and these enhance the expression of the author's love of the desert which pervades the book. The nineteen colour plates of birds, one by Thorburn, five by Lodge and thirteen by D. M. Henry, are excellent. The printing and general production are of a high order.

LANDSBOROUGH THOMSON

\section{"TEKTOPIA"}

Man and Energy

By Prof. A. R. Ubbelohde. Pp. $247+13$ plates. (London: Hutchinson's Scientific and Technical Publications, 1954.) 18s, net.

DROF. A. R. UBBELOHDE writes with the easy confidence of a master of his subject and has given us an agreeable and unusual book, ranging around the subject of man's relation with energy. While there is nothing that will be new to those schooled in thermodynamics, his treatment will attract the layman and give him an introduction to the sciences of energy. 'The book is in two parts, the first dealing with the growth of the use of power by mankind, and the second with the growth of knowledge on the subject. 'The first and historical part breaks away from the old story that has been told so often. Prof. Ubbelohde has absorbed and quoted a number of classical authors but rarely cited, and continually presents a new angle on the stery of power.

He introduces a conception new to me, one that is presumably his own, namely, that of the Tektopia. "Tektopias are theoretical constructions of ideal states, based on a large proportion of inanimate energy slaves." There would seem to be some doubt as to the merits of the Crreek construction Tektopia : presurnably it is a porimanteau word compressed from 'technological Utopia', but I think a Greek would suppose it to be a new disease, 'the condition of melting eyes' (cf., cutectic and myopia). Be this as it may, the word gives the opportunity for a discussion of that way of life, unhampered by the embarrassment of having to talk about the habits of particular countries.

The second half of the book is concerned with the foundation and growth of thermodynamics. This is never an easy subject to set before the public at large, but the author has done it as well as it can be done. The cosmic consequences of the laws of thermodynamics are considered-especially with regard to the heat-death of the universe. There is also a chapter on the thermodynamics of living creatures suggesting what seemed to me to be slightly fantastic possibilities of escape of living organisms from thermodynamic laws. The book is illustrated by some good plates and some amusing little diagrams. It is admirably free from misprints, though one of them, "the technological future of madkind", was a stroke of genius by the compositor. This is a book to be recommended to all who seek the wide and human view of science.

\section{F. Sherwood Tayior}

